\title{
Conrads clairobscur
}

I.

Med en vægt som var den fortællingen om denne litteraturhistoriske overgang, illustrerer Joseph Conrads roman Heart of Darkness ${ }^{1}$ fra 1902 den brydning imellem realisme og modernisme, som fandt sted omkring århundredeskiftet. Sammenstødet imellem de forskellige fortælleformer og verdensbillederne, som de formidler, lader sig på eksemplarisk vis iagttage inden for rammerne af denne roman. Traditionen udhules og af dens skal træder en ny opfattelses- og gengivelsesform frem, som ikke har forgængerens sikre beskrivelsesgrundlag, men hvis forfatter må navigere $i$ et virkelighedselement af en mere ufremkommelig natur.

Fortælleformerne udg $\emptyset \mathrm{r}$ i romanen to planer. Den moderne romans problematisering af traditionen har ikke blot hjemsted $\mathrm{i}$ forfatternes teoretiske skrifter, men $\mathrm{i}$ høj grad også $i$ romanerne, hvor den tages op til diskussion eller, som i Heart of Darkness, ligefrem er repræsenteret på et ydre plan, som modsættes det indre, det moderne. Det er i videre forstand sin egen skabelsesproces Heart of Darkness kommenterer. Med nedbruddet af realismen får litteraturen i stigende grad sig selv som tema og Heart of Darkness markerer tydeligt begyndelsen på denne udvikling. I litteraturens navlebeskuelse ligger bestræbelsen på en radikal modernisering. Man vil skabe en helt ny skrivemåde og erstatte realismens samfundshistoriske indhold med et mere autentisk, hvilket altså også bliver til problemer med dannelsen af den nye form. En væsentlig baggrund herfor er undsigelsen inden for alle områder af det kulturelle liv af de værdier, som bar det samfund realismen havde sat sig som opgave at skildre, således især udviklingstanken og tiltroen til objektive realiteter. En generel værdiopløsningsproces gør sig gældende og heri går det gamle beskrivelsesgrundlag under. Virkeligheden kompliceres og uoverskueliggøres gradvist og bliver dermed stadig vanskeligere tilgængelig for en objektiv betragtning. Udviklingen har kim tilbage i renæssancen, men slår for alvor igennem i Flauberts generation for at blive total hos 
generationen af moderne forfattere efter første verdenskrig. I ironien hos Flaubert spores besværet med at godtage almene værdier og hos ham erstattes det progressive tidsbegreb med begrebet om den destruktive tid, hvor vi skal se Conrad gøde jorden for den tidløshed, der fremme ved Joyce slår helt igennem $\mathrm{i}$ den cykliske romanform. På Joyces tid er værdiopløsningsprocessen permanent forstået som en næsten øjeblikkelig underminering af ethvert nyt tydningsfors $\emptyset$, hvormed den relative verdensanskuelse har sat sig fast.

Der er overensstemmelse imellem litteraturens nedbrud af den objektivt orienterede "ydre « realisme og nedrivningsarbejdet inden for naturvidenskaben, psykologien og filosofien af det hidtil godtagne fysiske og psykiske univers. Samfund, historie og objektive realiteter bliver et tvivlsomt indhold $\mathrm{i}$ litteraturen, der som et mere tidssvarende indhold ser de emner, der unddrager sig tiden. Man vil ned under det tidens tand alligevel gør værdiløst, ned til mere autentiske værdier og til de evige vilkår. I Heart of Darkness kan man iagttage skredet fra skildring af en konkret historisk situation til synliggørelse af »historien « blot i det omfang den afvises $i$ udsagnet om umuligheden af at skildre den og $i$ opfattelsen af den som illusion. Hinsides kritikken af historien og dens frembringelse, civilisationen, fremkommer den opfattelse af virkeligheden som dybest set ubevægelig og uudgrundelig, der bliver bærende $\mathrm{i}$ mange moderne romaner. Denne dybere sandhed om tilværelsen er af så grufuld en natur, at fortælleren Marlow i Heart of Darkness delvist forsones med civilisationen, ser en nødvendighed i den skærmende illusion. Men tvetydigheden er hele tiden til stede. Meningsløsheden som tilværelsens inderste rummer samtidig en hidtil uanet frihed, som også er friheden til at skabe. Således er en af romanens triumfer opdagelsen af dét ubegrænsede, der åbner sig, når mennesket aflægger sit civiliserede tidsbestemte jeg, den skaberkraft, der ligger $\mathrm{i}$ det tidløse og umiddelbare indre. Heart of Darkness er frontkæmper i det moderne fremstød, der sprænger den rationelle overflade og ser ned $i$ bevidsthedens dybere lag. Jubelen over mulighederne i dét indre, som udvider sig voldsomt, idet det ydre fra og med Flaubert viger som troværdigt beskrivelsesobjekt, denne ydre virkeligheds atomisering og de stærke modsætninger $i$ tiden, såvel som de vanskelige betingelser for at skrive det afføder, fremgår af følgende citat af Virginia Woolf, en af de forfattere Conrad baner vejen for:

"Det er en tid, hvor vi tydeligvis ikke ligger fast forankret... Sindet er fuld af monstrøse, blandede, uregerlige følelser; at jorden er 3.000.000. 000 år gammel; at menneskelivet blot varer et sekund; at der ikke desto 
mindre ingen grænser er for den menneskelige bevidstheds kapacitet; at livet er uendelig smukt og dog frastødende; at ens medmennesker er henrivende og dog modbydelige; at videnskaben og religionen $i$ fællesskab har nedbrudt troen; at alle enhedsbånd synes brudte, og at der dog må være en form for kontrol - det er i denne atmosfære af tvivl og konflikt, at forfatterne nu skal skabe, og den traditionelle form er ikke bedre egnet til at rumme dette synspunkt, end et rosenblad til at omslutte en klippes kantede umådelighed.« (s. 11-12) ${ }^{2}$

Heart of Darkness kaster lys over det spændingsfelt, hvori romanen endeligt mister sin uskyld. Grebet om en hel, overskuelig virkelighed med et sæt af alment accepterede værdinormer, som langsomt var løsnet, ophører i den tidlige modernisme, som Heart of Darkness tilhører, og romanen træder ind i et æstetisk stadie med kendetegn som selvspejling, mangfoldighed, relativitet og dobbeltheden af frigørelse, udvidelse og indskrænkning eller indesluttethed med dens fare for dæmoni. Den historiske udvikling umuliggør et overordnet point-of-view - kulturelt og derfor også romanteknisk. Heart of Darkness har reminiscenser af den tradition, hvori fortælleren umiddelbart og alvidende kunne fortælle løs, og samtidig træder den atmosfære frem, som ovenfor får Virginia Woolf til at anse en helt ny litterær form for nødvendig, hvis tiden skal kunne rummes i den. Den alvidende fortæller træder tilbage med Flauberts teori om den upersonlige kunst, hvori »forfatteren, ligesom Gud i verdensaltet, altid bør være til stede, dog aldrig synlig. ${ }^{3}$ Conrads fortællers kamp med materialet og hans diskussion af mulige opfattelses- og gengivelsesformer betegner yderligere et skridt $i$ retning af den mangfoldiggørelse af synsvinklerne, som kommer til at præge romanen og vidner om besværet med at udtrykke tiden og om den relativisme, der kulminerer i Joyces einsteinske univers.

Litteraturen i det syttende og attende århundrede trækker på »virkelighedsmaterialet « primært for at illustrere moralske spørgsmål. Den får status af »middel « i en højere tjeneste. Det nittende århundredes realisme bekender sig til virkeligheden $\mathrm{i}$ bred forstand, og gengivelsen af den bliver det primære. Opgøret med realismen og opkomsten af modernismen er ét stort spørgsmålstegn ved »realiteter«, som nu udspaltes i mangfoldige subjektive størrelser; der opstår igen en tendens til, at virkelighedsmaterialet bliver et middel - for astetiske øvelser - eller kunsten rangeres over livet, hvor den ligefrem tildeles en rolle som "virkelighedsskaber «. Det empiriske element udrangeres fordi det bliver et område undermineret af den tiltagende relativisme, men i Joyces og Woolfs generation 
finder vi stadig en søgen efter noget universelt af større gyldighed. Det voksende opgør med udviklingstanken og objektive realiteter er aflæselig i den ydre handlings gradvise svinden ind. I de tidlige ridderromaner er strukturen episodisk: en episk fortælleform, hvori gengives en mangfoldighed af selvstændige episoder uden egentlig hensyntagen til en overordnet helhed andet end den uendelige profilering af heltens karakter. Man er fra begyndelsen i romanens midte og forløbet er cyklisk: den uendelige gentagelse, tilbagekomsten til udgangspunktet. I det attende århundrede træder princippet om enhed og udvælgelse og om én fremadskridende handling i stedet, det cykliske tidsbegreb erstattes af et lineært, progressivt. Denne kompositionsform behersker det nittende århundredes realisme, men kommer under tryk i slutningen af århundredet, hvor $\mathrm{i}$ den tidlige modernisme den ydre (samfundsmæssige) handling - eller »plottet «, som kræver »begyndelse, midte, slutning « (bevægelse frem $i$ tid) - nedbrydes. I den senere moderne roman genoplives det episodiske og cykliske mønster, hvorved romanerne bliver uendelige (open-ended) og "plotless « $i$ den forstand, at plottet reduceres til at være det udramatisk skildrede bevidsthedsarbejde, som reflekterer en banal hverdag, der ikke bevæger sig synderligt. Heart of Darkness illustrerer handlingens sammenbrud og dermed den romanhistoriske krise, der nok har årsager $\mathbf{i}$ det historiske pres tidens forfattere er underlagt, men samtidig er en periode med eksplosiv frisættelse af nye kunstneriske muligheder og med lettelse efterhånden som man skriver sig fri af det tunge historiske arvegods.

II.

Heart of Darkness har to fortællerlag: sømanden Marlow, der på en sejlbåd forankret på Themsen til sine kolleger beretter historien om sin deltagelse i en ekspedition op ad en flod i Afrika, og det tilstedeværende fortæller-»Jeg«, som introducerer, kommenterer og afrunder »scenen « på båden. Fortælleren lægger sine kommentarer ind, hvor Marlow holder pause $\mathrm{i}$ beretningen, som $\mathrm{i} \emptyset \mathrm{vrigt}$ blot afbrydes af de spørgsmål fra tilhørerne, der ikke fremgår eksplicit, men som man ud fra Marlows tale kan forstå er stillet, hvortil kommer de spørgsmål Marlow selv stiller sit publikum, blandt andet om de opfatter »historien « og ikke mindst de bemærkninger han i forlængelse heraf gør om sin fortællings karakter.

De er på lystsejlads med bådens indehaver, direktøren for det selskab, som Marlow og »Jeg« og de øvrige deltagere, en advokat og en revisor, 
er ansat i. Marlows publikum tæller således fire personer. Det er med storbyen London i baggrunden, at de mageligt slængt på dækket kan lytte, men at Marlow overhovedet kommer til orde skyldes tidevandet, som tvinger båden til at ankre op. Marlow begynder sin fortælling ved højvandets komme og slutter den, da ebben sætter ind. Hans beretning aflægges under kultiverede former og med civilisationens højborg som kulisse, men det er naturens kræfter, som sætter den igang. Historien påbegyndes ved solnedgang og har dermed sit udspring, sin kilde, $\mathrm{i}$ brydningen imellem lys og mørke.

Marlow fortæller om sin ansættelse $i$ et oversøisk handelsfirma, for hvem han fører en båd igennem et svært tilgængeligt jungleområde fra den yderste handelsstation til "den inderste station « dybt inde $\mathrm{i}$ landet, hvis leder er den legendariske Kurtz, som har varet en af firmaets mest lovende mænd, men som nu siges at være blevet gal og have gjort sig til en gud for de indfødte. Den junglesejlads, der er beretningens emne, har således karakter af alt andet end lystsejlads, men modsætningen er kun tilsyneladende. Det er beretningen om en rejse imod et mål af en meget sammensat natur. For Marlow går rejsen retur, mens Kurtz, som Marlow har til opgave at bringe ud, bliver derinde. Det er rejsen fra civilisationen tilbage til naturen og fra historieskabelsens århundrede tilbage til før der (som beskrevet i Første Mosebog) sattes skel imellem lys og mørke - til det "Intetsteds ${ }^{4}$ som Kurtz er trådt $i$ forbindelse med. Tiden ophæves $i$ takt med Marlows indtrængen i junglen, men han bevæger sig ikke blot væk fra fremskridtet ind $\mathrm{i}$ evigheden, hans deltagelse $\mathrm{i}$ overførelsen af civiliserede tilstande til det uudviklede land understreger, at der i høj grad samtidig er tale om en konfrontation imellem yderpunkterne. Den historiske realitet imperialismen optræder i rejseberetningen, men underordnes en mere generel diskussion om historie og civilisation efterhånden som Marlow trænger ind $\mathrm{i}$ junglen. Rejsen er ikke mindst en bevægelse indad forstået som Marlows voksende erkendelse og som bevægelsen imod de oprindelige, »uciviliserede« naturdrifter. Den kulminerer i mødet med Kurtz, som er Marlows inderste og som netop artikulerer den mulige »visdom « samtidig med, at han demonstrerer konsekvensen af at være ribbet for det civiliserede lag. Vi har dermed to planer, et samfundshistorisk og et personligt, erkendelsesmæssigt, som er tæt sammenskrevne og man kan tale om en glidning fra det konkret historiske over den almene diskussion af civilisation og historie til det subjektive. For planerne gælder en høj grad af flertydighed, hvor det ubestemmelige eller værdiløse ender med at blive et udsagn i sig selv.

Igennem beskrivelsen af handelsfirmaet gives et billede af datidens 
fremturende imperialisme, hvori de lyssky midler og pauvre mål bag facaden stilles til skue. Som Marlow selv konkluderer: »At hale rigdomme ud af landets skød, det begærede de, med så lidt moralsk formål til at bakke det op, som hos indbrudstyve der brækker ind i et pengeskab« (s. 43). Denne hårde kritik, som understreges af beskrivelsen af udpinte og døende slaver, gælder imidlertid afvejene, mens der $i$ romanen er en stærk tendens til ukritisk accept af det civiliserende arbejde i uudviklede lande som sådan. Hvor det hedder, at »hele Europa bidrog til at skabe Kurtz« (s. 70), sigtes der således til de oprindelige gode hensigter og det faktiske brutale overgreb han på én gang personificerer. Skellet er sat imellem før og efter Kurtz blev gal - imellem »den oprindelige Kurtz« og »dette indviede genfærd, der kom længst ude fra Intetsteds« (s. 70). Før har han skrevet en rapport, der var en "gribende appel til enhver altruistisk følelse« (s. 71), men gentagne gange i romanen beklages det, at moralen er gået tabt som følge af Kurtz galskab og at han dermed har udmeldt sig af »dydernes hold « (s. 36) for i stedet at tiltage sig djævelens magt.

De hvides nødvendige overherredømme i bestræbelserne for at bringe civiliserede tilstande og økonomisk fremskridt til de uudviklede (vilde) lande under forudsætning af, at det uegennyttige og godgørende ligger bag bestræbelserne - dertil går romanen i opstillingen af et alternativ til Kurtz' og dermed Europas ekstreme udnyttelse af kolonierne. Alternativet har en naiv romantisk karakter og med indskrivningen af dette ideologiske plan tages brodden af den oprindeligt skarpe kritik. Denne »inddæmningsstrategi ${ }^{5}$ fortsættes på flere måder. Allerede nævnt er opbygningen af modsætningen imellem den gode og onde fremgangsmåde, som er anvendt på det realistiske plan til at vise det »djævelske« som den anden, skjulte side, men med den ideologiske inddæmning ender ondskaben samtidig udenfor - den bliver en absolut modsætning og optræder som det farlige, der truer de uangribelige gode hensigter. Hermed får vi på en gang et melodrama à la Balzac, hvor grebet anvendes til at afsløre de skjulte sammenhænge, og et mere ordinært, hvor modsætningen består og slører samme sammenhænge. Således brydes i Heart of Darkness et realistisk plan med et ideologisk, hvilket har en udvanding af romanens kritiske potentiale til følge. Foruden den ideologiske inddæmningsstrategi er den diskussion af civilisation og historie, som er overbygget skildringen af den konkrete historiske imperialisme, betragtelig som en sådan strategi - fordi den ganske enkelt er langt mere omfattende og således »optager pladsen «, hvortil kommer dens abstrakte karakter, som ikke bidrager til at synliggøre det konkret historiske, men især fordi diskussionen 
indeholder udsagn, som delvist undskylder eller gør imperialismeskildringen mindre offensiv. I kølvandet herpå følger, som vi skal se, en »eksistentialistisk strategi« og sluttelig den, som ligger i subjektiveringen af universet, hvormed det ydre dels bliver symbol på det indre, dels opløses i subjektive indtryk.

Civilisationen, som Marlow bevæger sig væk fra, men samtidig er med til at overføre og som han i modsætning til Kurtz vender tilbage til, er udsat for en kritik følgende Marlows »bevægelse«: den intensiveres i takt med hans gradvise indtrængen $\mathrm{i}$ naturen for at kulminere $\mathrm{i}$ mødet med Kurtz, hvorfra en modificering begynder, som fører til accept af civilisationen, men under indtryk af de gjorte erfaringer »udenfor«. Det er så at sige fra sit slutpunkt, at Marlow fortæller; på Themsen med London »den største og vældigste by på jorden« (s. 5) - i horisonten og som han siger til sine tilhørere: "Her sidder $I$ alle sammen fortøjet med to gode adresser, som et stort skrog med to ankere, en slagter omkring det ene hjørne, en politibetjent omkring det andet, udmærket appetit, og temperaturen normal - ka' I høre - normal fra den ene til den anden ende af året« (s. 67). Normalitet og tryghed og strabsomhed, arbejde, er ingredienser $\mathrm{i}$ beskrivelsen af det civiliserede liv. Således er det rutinearbejdet på båden Marlow klynger sig til, hvor han i begyndelsen forsvarer sig imod de nye indtryk: »Jeg gik $\mathrm{i}$ arbejde den næste dag... kun på den måde, forekom det mig, kunne jeg bevare mit greb om livets forsonende fakta« (s. 32). Hvad Marlow fører med sig er også »en verden med ligefremme fakta« (s. 20) og som Kurtz var det, er han agent for »medfølelse, og videnskab, og fremskridt« (s. 36).

Vi har at gøre med en kompleks natursymbolik, idet den på tre forskellige måder har til opgave at kaste lys over denne civilisation. Den danner et positivt modbillede, viser ned under »overfladen « og den skaber et skræmmebillede.

Modbilledet trækker på de idylliske sider ved naturen og ved de indfødte, som her er ét med naturen. Vasentlige kvaliteter, som naturen tillægges i modbilledet, er frihed, meningsfuldhed (virkelighed, sammenhæng) og umiddelbar (spontan, intuitiv) selvudfoldelse. Marlow siger: »dér kunne man se på en ting der var monstrøs og fri« (s. 51), hvor det monstrøse her er at forstå som bevægelsesfrihed (i tråd med den karakteristiske flertydighed peger det samtidig på det uhyre og ukontrollable, hvorom senere) og da han føler sig ensom på båden, hedder det om brændingen og om indfødte i en kano: »Brændingen...var noget naturligt, der havde sin ræson, der havde en mening. En båd kom nu og da fra kysten og gav én en kortvarig kontakt med virkeligheden. Den blev padlet 
af sorte fyre...de havde...en vild vitalitet, en intens energi $\mathrm{i}$ bevægelsen, der var så naturlig og ægte som brændingen langs deres kyst« (s. 20). Modbilledet trækker det fraværende i civilisationen frem. Det understreger den moderne verdens uvirkelighed, formålsløse energiudladning og mangel på frihed og mening. Det civiliserede liv, som bygger på amputation og på en rationel tænkning, der er utilstrækkelig og usand, får handelsfirmaets bogholder eftertrykkeligt fastlagt i følgende beklagelse: „Når man skal foretage korrekte indføringer, kommer man til at hade de dér vilde - hade dem til døden« (s. 27).

Naturindtrykkene ændrer Marlows opfattelse af den verden, han har forladt; hvor før rutinearbejdet på båden fastholdt hans »virkelighed “ under presset fra de uvirkelige omgivelser, vendes dette forhold nu om; arbejdet, som han her igen omtaler, bliver da symbol på den overfladiske kultur, der holder virkeligheden ude: »Når man skal være opmærksom på den slags ting, de blotte hændelser på overfladen, er det at virkeligheden - jeg siger jer, virkeligheden - udviskes « (s. 49). Marlow skelner stadig klarere imellem »overfladisk sandhed « (s. 52), det som er fremme i lyset, og den større sandhed, som »lå langt under overfladen« (s. 55), hengemt i mørket. Forholdene udenfor lov og orden - $\mathrm{i}$ junglen - som et billede på samfundets skyggeside, er klart angivet i beskrivelsen af to kvinder, som Marlow møder på handelsfirmaets hovedkontor, hvor de er en slags receptionister. Her knyttes det bedsteborgerlige, hyggelige, direkte sammen med uhyggen, vildskaben og døden, lys med mørke. Som et par viktorianske bedstemødre sidder kvinderne mageligt i kurvestole og strikker, den ene ovenikøbet med en kat på skødet, sølvbriller på næesen og fødderne, der er stukket $i$ et par hjemmesko, mageligt anbragt på en fodvarmer. Med en for romanen atypisk utvetydighed hedder det i samme pennestrøg, at disse to »bevogtede Mørkets dør, strikkede sort uld som til et varmt ligklæde...introducerede uafbrudt til det ukendte « (s. 16). Det er naturligvis den dødbringende imperialisme, som det oversøiske handelsfirma er eksponent for, der sigtes til, men kolonimagternes overgreb på naturrigdommene medvirker som et ekstremt billede $\mathrm{i}$ det generelle udsagn om den naturundertrykkelse, der finder sted $i$ civilisationen. Derfor er dørvogterne inkarnationen af familiær idyl. Det ligklæde kvinderne strikker skal dxkke over den død, som er den mørke, skjulte side af civilisationen, hvor døden ikke mindst er at forstå som den fortrængning og bortskæring civilisationen bygger på. Tilstandene $\mathrm{i}$ junglen som et billede på konsekvensen af denne naturundertrykkelse får en bizar understregning, da kvindernes garnnøgle senere viser sig at vokse på en døende slave, hvorom det hedder, at han lod »sit uldne hoved falde 
ned på sine brystknogler« (s. 25).

Det er især i skildringen af Kurtz' galskab, at vi ser konsekvensen af den naturundertrykkelse, som han selv $i$ højeste grad eksekverer. Også Kurtz forbindes direkte med de to kvinder. Da Marlow ser ham i al sin elendighed, kravlende på alle fire i junglens søle, træder »den strikkende gamle kone med katten « frem for Marlow som siddende »ved den anden ende af sådan en affære « (s. 92). I øvrigt er den kat, som bedstemoderen flere gange tildeles, sandsynligvis en af de »civilisationens døde katte« (s. 71), som Marlow omtaler andetsteds - med den klare besked om aflivningen af det selvstændige og naturlige, som ligger heri. Kurtz er i bedste Kierkegaardske forstand dæmoniseret. Med undertrykkelsen har lidenskaben i ham antaget monstrøse former, hvoraf følger selvudslettelse og disse forhold skaber den angst, som $\mathrm{i}$ romanen udbasuneres under betegnelsen »rædslen, rædslen «. Naturen er ikke blot det betvungne, men lignes også med en organisme, der forsvarer sig imod de indtrængende civiliserende kræfter: »den formløse kyst, afgrænset med en farlig brænding, som om Naturen selv havde prøvet på at holde ubudne gæster væk« (s. 21). Således begrundes Kurtz galskab med det forhold, at den undertrykte natur slår igen eller, som Marlow siger, den hævner sig: »vildnisset havde gennemskuet ham tidligt, og havde taget en frygtelig hævn over ham for den fantastiske invasion « (s. 82). Hævnen er grusom og der lægges ikke fingre imellem i beskrivelsen af den. Kurtz ribbes i ordets værste betydning for sit civiliserede lag (selv), hvor elfenben her optræder som symbol for denne totale selvudslettelse, død, der reducerer ham til et fossil: "vildnisset havde klappet ham på hovedet, og se dog, det var som en kugle - en elfenbenskugle...Han var visnet; det havde taget ham, elsket ham, omfavnet ham, gået i blodet på ham, fortæret hans kød og forseglet hans sjæl til sin egen sjæl, ved de ufattelige ceremonier i en eller anden djævelsk indvielse « (s. 68). ${ }^{6}$

Dæmoniseringen af Kurtz angiver, at der er grænser for naturbetvingelsen og dermed en lovmæssighed man ikke bør overskride. Men dette står i modsætning til den anden betydning af Kurtz' given sig naturen i vold. »Dæmoniseringen « betegner det højeste punkt $\mathrm{i}$ kritikken af civilisationen, men med det billede af en vild og ukontrollabel natur, som her fremmanes, begynder samtidig tilbagetoget, det vil sige opblødningen af kritikken. Kurtz, som præsiderer $\mathrm{i}$ de inderste og vildeste egne af det uciviliserede land, er ikke blot et offer for sin nådesløse naturbeherskelse, men også en mand, som er vendt tilbage til naturen, til den forhistoriske tid: »At komme op ad den flod var som at rejse tilbage til verdens tidligste begyndelse...en tom strøm, en vældig stilhed, en uigen- 
nemtrængelig skov. Luften var varm, tyk, tung, trægtflydende. Der var ingen glæde ved solskinnets funklen...vi var vandrere på en forhistorisk jord, på en jord der havde et udseende som en ukendt planet « (s. 48 og 51). Det ægte og uforfalskede, men samtidig det uvisse og uhyggelige, som mere direkte benævnes »en infernalsk strøm, strømmen af mørke« (s. 108), er hvad Kurtz har taget bolig i. Hans ord »rædslen, rædslen« er på én gang en dom over den angstskabende civilisation, han har forladt, og over den »oprindelige jord«, som han begraves i eller lader sig opsluge af. Kurtz dør som følge af sin galskab påført af den hævngerrige natur, men selvudslettelsen kan også ses som den villede og totalt kompromisløse rejse (flugt) bort fra den undertrykkende civilisation, hvor forvandlingen til et forssil da tilkendegiver Kurtz' fuldkomne hengivelse til urkræfterne, det oprindelige og sande. Denne modsæatningsfyldte dødsattest underskriver Marlow idet han vedbliver med på en gang at kalde Kurtz "gal « og »fuldstændig klar « (s. 94), men der er forbindelse derved, at dæmonen i Kurtz samtidig er den faustiske pagt med djævelen, som er en velkendt kilde til erkendelse.

For Marlow er Kurtz' død dog især demonstrationen af det umulige i at leve uden for civilisationen og det vil sige demonstrationen af civilisationens nødvendighed: "Sagen var at vide, hvad han tilhørte, hvor mange mørkets magter, som krævede ham som deres...I kan ikke forstå det. Hvordan skulle I det? - med et solidt fortov under fødderne, omgivet af rare naboer...I, der træder så sart mellem slagteren og politibetjenten...hvor kan I forestille jer, hvilken særlig egn i de første tider en mands uhindrede skridt kan føre ham ind $i$, ad ensomhedens vej - den fuldstændige ensomhed...Disse små ting gør hele den store forskel. Når de er borte, må man falde tilbage på sin egen medfødte styrke...Selvfølgelig kan man være...altfor $d ø d$ i det, til bare at vide at man overfaldes af mørkets magter« (s. 69). I modsætning til Kurtz vender Marlow tilbage til det normale liv, som opholdet $\mathrm{i}$ junglen har øget irritationen overfor og hvis overfladiskhed han har erkendt. Men det sker med bevidstheden om, at det civiliserede liv trods falskhed og banalitet yder en livsnødvendig beskyttelse imod »mørkets magter «. Kurtz er trådt over »tærsklen til en evigheds mørke« (s. 107), som også kaldes »tærsklen til det usynlige« (s. 100), mens Marlow tilkendegiver, at "jeg fik lov til at trække min fod der tøvede tilbage. Og måske ligger i det hele forskellen« (s. 100). De forhold Marlow møder »udenfor « civilisationen, $\mathbf{i}$ junglen, udsiger den dybere sandhed om tilværelsen og det er Kurtz, som formulerer denne »inderste " sandhed: frygt og uvished. Konfronteret med den grufulde sandhed under overfladen, får overfladen, det civiliserede liv, tilbagegivet sit værd. 
Der er »overfladisk sandhed nok i disse sager til at frelse en klogere mand « (s. 52), har Marlow sagt om arbejdet på båden og $\mathrm{i}$ romanens slutscene, hvor han et år efter sin hjemkomst opsøger Kurtz' forlovede, undlader han at fratage hende den »store og frelsende illusion« (s. 107), der er afbildet som en glorie om hendes hovede. På hendes forlangende om at høre Kurtz sidste ord - som begrundes med ønsket om at få noget at leve for, et livsgrundlag! - siger Marlow, at det var hendes navn, hvormed han fortier, at det i virkeligheden var den »rædslen «, som Kurtz udtalte hinsides tærsklen til det evige mørke. Dermed bekræfter Marlow de storartede borgerlige dyder, som Kurtz' forlovede er indbegrebet af og samtalen igennem understøtter han den glorificering af Kurtz, som hun ihærdigt arbejder på. Slutscenen er en veritabel miniatureudgave af romanens kamp imellem lys og mørke og selv om Marlows møde med tilværelsens barske realiteter derude i det evige mørke får ham til at se lyset $\mathrm{i}$ civilisationens store illusionsnummer, så făr vi imod slutningen blot en understregning af det uophørlige $\mathrm{i}$ denne kamp. Marlow bevarer illusionen hos Kurtz' forlovede, men den plade han stikker hende har en anden og sand side. Kurtz' forlovede er en Madonna, ren og uskyldig, den ideelle hustru, hun fremtræder bl.a. »oplyst af tiltroens og kærlighedens uudslukkelige lys (s. 106). Som kvinderne, der vogter indgangen til mørket, repræsenterer hun den institution, der holder lidenskaben indespærret. Det hun står for er også det, der fremkalder angst, hvorfor Marlow ikke nødvendigvis lyver, da han fortæller hende, at Kurtz sidste ord var hendes navn, der forbliver uudtalt, men som altså kan være identisk med eller dækkende for den ubeskrivelige »rædslen« Kurtz dør med på læben.

Det flertydige ved Kurtz' forlovede udtrykkes bl.a. således: »Dette blonde hår, det blege åsyn, den rene pande var som omgivet af en askegrå strålekrans, hvorfra de mørke øjne så ud på mig. Deres blik var troskyldigt, dybt, fortroligt og tillidsfuldt « (s. 105). Engleagtig på overfladen, men øjnene, der melder om det dybereliggende, er mørke! Formuleringen "så ud« henleder tanken på indespærring og på bunden af det mørke Marlow ser ind $i$, kan den vilde kvinde, som Kurtz holdt sig $i$ junglen, befinde sig. Om hende hedder det, at hun er »som vildnisset selv« (s. 87), hvilket er den naturlige udfoldelse, som Kurtz' forlovede er modsætningen til, og den undertrykte lidenskab $i$ hende, som er resultatet heraf. Blandingen af lyst og mørkt er angivet i den »askegrå strålekrans«, der omgiver Kurtz' forlovede, hvor farvesymbolikken ligefrem peger på den mediering, som Marlows tilbagekomst signalerer, hvilket han andetsteds understreger ved at kalde det erkendelsesstadie han når for »en gråhedens vision« (s. 100). 
Den englehvide kvinde, der har mørket i sig, genfindes $i$ form af det elfenben, der anvendes som smykke, men egentlig, $i$ grunden, er døden. Døden findes dog i absolut nærhed af Kurtz' forlovede, som modtager Marlow klædt i sørgedragt og i et rum, der meget direkte lignes med et gravkammer: "Den høje marmorkamin var kold og monumentalt hvid. Et flygel stod massivt i et hjørne, med mørke lysstrejf på de glatte overflader som en dyster og poleret sarkofag" (s. 105). Sarkofagen og det isnende kolde ildsted, ovenikøbet af det elfenbenslignende marmor, taler tydeligt om den død, som Kurtz' forlovede vogter over. Som de to kvinder ved civilisationens port, har hun lig i lasten, men sarkofagen kan samtidig være Kurtz', hvilket da knytter sig til det aspekt ved hans død, der angav forhold i civilisationen som årsag, mens den tidligere oplysning om hans begravelse $\mathrm{i}$ oprindelig jord talte om hans kompromisløse hengivelse til urkræfterne, det oprindelige og sande. I hvert fald modstilles to forskellige forestillinger om døden: den barske, men naturlige forsvinden $i$ et »mudderhul«, som Marlow også kalder Kurtz' grav derude, og opbevaringen i sarkofagen, som adskiller sig fra en almindelig kiste ved sin kunstneriske udsmykning og ved sin monumentalitet. Sarkofagen hæver sig over dét jordiske, som Kurtz har hengivet sig til derude, men som er fortrængt $\mathrm{i}$ det miljø hans forlovede repræsenterer. Imidlertid har "sarkofag" en oprindeligere betydning, som minder om det skjulte i dette miljø, om rådenskaben bag monumentaliteten; betegnelsen dækkede egentlig kister lavet af en stenart, som hurtigt opløste kødet, sarkofag betyder også »kødæder«. Hermed repeteres skeletteringen af Kurtz og den behandling han selv udsætter slaverne for, men samtidig melder forestillingen sig om blodsugeren, vampyren, der holdt under låg af lyset, huserer i mørket.

Men kendetegnende for mørket er også bestandigheden. I romanen hører evigheden mørket til, mens tiden er blændværk. Mørket dækker frygten og uvisheden, som var den »inderste « sandhed om tilværelsen. Er "sandheden klædt nøgen for sit slør af tid « (s. 52), har man dette fundamentale, tidløse vilkår, som kun tilsyneladende står i modsætning til det beskrevne modbillede, hvori naturen - og de indfødte som en organisk del af den - tillagdes kvaliteterne harmoni og meningsfuldhed. Spørgsmålet om »mening « får en anden og mere historisk dimension, hvor Marlow om de indfødtes trommer siger, at de meddelte sig "måske med en lige så dyb betydning som lyden af klokker i et kristent land « (s. 28). Kirken som stedet for primitiv meddelelse og antydningen af tabet af mening som følge af en historisk udvikling (en reel historisk registrering: verdsliggørelse, værdiopløsning osv.) ligger heri, men især anes en ironi 
over muligheden af en anden og mere betydningsfuld tid. Modbilledet har i sidste instans ikke den kritiske funktion at angive en utopi, hvori er nedlagt muligheden for forandring, men tjener blot til at fremhæve, hvad der til evig tid er uden for civilisationen, det vil sige fraværende i verden som sådan. Denne anden og dybere betydning af modbilledet er underbygget $i$ de generelle udsagn, der fremkommer om tilværelsen og i flere angreb på historien.

I Marlows opsummering af sin og Kurtz' visdom hedder det i nu almene vendinger om livet: "Munter ting, livet - dette mystiske arrangement af ubønhørlig logik til et nytteløst formål...hvis det er den form, den højeste livsvisdom antager, så er livet en større gåde, end nogen af os tror det er...en ufattelig verden, der ikke havde håb i sig og ikke begær « (s. 99-100). Hvad der i første omgang var eller på et plan er en kritik af samfundshistoriske forhold svinder således ind til at blive et eksistentialistisk suk over et eviggyldigt vilkår. Det meningsløse og udefinerlige ophøjes til at være den skjulte sandhed $i$ en verden, som tror sig $i$ bevægelse imod stadig bedre forhold. Ironien over historien anslås fra begyndelsen, hvor det om det civiliserede England hedder: »Også dette her «, sagde Marlow pludselig, "har været et af de mørke steder på jorden...da Romerne først kom her, for nitten hundrede år siden forleden dag...mørket var her igår « (s. 8-9). Så enkelt kan romanen også ophæve tiden. Historien gentager sig eller det Schopenhauerske "alt er til enhver tid det samme «, dog $\mathbf{g} \emptyset \mathbf{r}$ Marlow her den forskel, at romerne ikke lagde skjul på den brutalitet, som kolonisterne på Marlows tid gemmer bag »et sentimentalt påskud « (s. 10), hvilket han også formulerer således, at romerne var »mænd nok til at se mørket lige i øjnene« (s. 9), uden omsvøb efterlevede tilværelsens grundlov, jungleloven.

Kurtz' arbejdsplan var, at »hver enkelt station skulle være som en bavne på vejen til bedre ting, et midtpunkt for handelen, men også for at humanisere, forbedre, undervise« (s. 47), hvorved han peger på det almene $i$ sin rolle som civilisator. Kurtz' indtrængen $i$ junglen viser os civilisationsprocessen i sammentrængt form og angiver forgængeligheden som dens inderste kerne, den fører blot til »den lurende død, det skjulte Onde, det dybe mørke i hjertet på det « (s. 47). Civilisationen er et tidsligt fænomen, en døgnflue målt med evighedens alen; om den natur, den vildskab, som menneskeheden ihærdigt søger at kultivere, hedder det gentagne gange, at den grænselø̣st tålmodigt venter "på at denne fantastiske invasion skulle gå bort« (s. 47). Individ som slægt vil uafvendeligt synke ned $\mathrm{i}$ »den glemsel som er vores fælles skæbnes sidste ord« (s. 103). Romanen tøver ikke med at lokalisere »fremskridtets 
skraldespand« (s. 47), som kunne være indskriften på det gravmæle den sætter over fremskridtets århundrede, dét nittende, hvis faldereb romanen er skrevet på. Kurtz' forlovedes bopæl antager mausoleets dimensioner. Fremfærden imod udvikling og historie er almen, men har naturligvis rod i det århundrede, der ifølge Nietzsche bød på et »overmål af historie « 7 Allerede i 1870'erne angreb Nietzsche frontalt de værdier, hvorpå den vestlige kultur var bygget. Han talte for en »omvurdering af alle værdier« og stillede sig særdeles kritisk overfor netop udviklingstanken, historien, som han anbefalede disse midler imod: »Midlerne imod det historiske hedder - det uhistoriske og det overhistoriske...Med ordet »det uhistoriske « betegner jeg kraften og kunsten at kunne glemme og lukke sig inde i en begrænset horisont; »overhistoriske« kalder jeg de magter, der leder blikket væk fra udviklingen hen til det, der giver tilværelsen karakter af det evige og uforanderlige, til kunst og religion. Videnskaben ser $\mathrm{i}$ hin $\mathrm{kraft}$, i disse magter fjendtlige magter og kræfter; thi den eneste måde at betragte tingene på, som den regner for den sande og rigtige, altså for den videnskabelige, er den, der overalt ser noget opstået, noget historisk og intetsteds noget værende, evigt « (s. 99-100). Denne recept er fulgt i Heart of Darkness, hvis historiekritik er af samme flerstrengede karakter. Den vil ikke blot noget til livs, men også være skabende. Ved anvendelsen af det overhistoriske middel fremkommer udsagnet om det mistrøstige evige vilkår, men det tunge historiske arvegods søges også manet $\mathrm{i}$ jorden som det, der dræber evnen til at skabe umiddelbart og frit, netop uhistorisk.

Det er angivet, hvorledes et realistisk og kritisk plan brydes med og nedbrydes af en række »inddæmningsstrategier«, som dels er den ideologiske trækken i land, dels diskussionen af civilisation og historie, som fører vak fra det konkrete og over $i$ almene og abstrakte overvejelser, hvilke igen fører til et eksistentialistisk udsagn og en historieopfattelse, som gør det, der på det kritiske plan syntes at være et angreb på foranderlige forhold til et udsagn om evigt tilbagevendende og derfor uforanderlige forhold. Bevægelsen væk fra realisme inden for romanens rammer manifesterer sig $\mathrm{i}$ yderligere to forhold: $\mathrm{i}$ den ydre rejses (diskussionen af historiske forhold) derealisering, idet den bliver udtryk fra en indre erkendelsesmæssig, og i den hermed forbundne kamp imellem en traditionel (ydre) og en moderne (indre) fremstillingsmåde, hvormed vi kommer tilbage til den umiddelbare, uhistoriske skabelse.

Marlows rejse er også en bestræbelse for at få klarhed over sig selv. Bevægelsen ind i vildnisset er en indre opdagelsesrejse, som fører væk fra det civiliserede jeg, overjeg'et, og ned i de dybere regioner af bevidstheden. Den kulminerer i mødet med Kurtz, som her personificerer 
Marlows »inderste «, hvilket er et forhold, som understreges flere steder, således f. eks.: »Jeg tog op af den flod til det sted, hvor jeg først mødte den stakkels fyr. Det var det fjerneste punkt man kunne sejle til, og det kulminerende punkt i mine erfaringer. Det var som det på en eller anden måde kastede en slags lys over alt omkring mig - og ind i mine tanker« (s. 11). Skildringen af mødet med det ubevidste, de »inderste « egne, er igen dobbelttydig. Der er p̊̊ den ene side befrielsen ved at have aflagt »selvet«; strøget besværlighederne ved det kontrollerede jeg og overgivet sig til ren umiddelbarhed, som Kurtz siges at have gjort: "forsvandt $i$ ugevis; glemte sig selv mellem disse folk - glemte sig selv« (s. 80), men på den anden side er der de vilde naturdrifter, som hersker her: den rå og hensynsløse, dyriske adfærd, som Kurtz lægger for dagen. Igen er forholdet, at denne vildskab fra at være på vej til at blive betragtet som udslag af rigid drifts- eller naturbeherskelse - havende individualhistoriske årsager - ender under påstemplingen: færdig fra naturens hånd. Marlow vender tilbage for ikke at blive "selv«-udslettet som Kurtz, hvorom det jo hedder, at han begraves $i$ oprindelig jord. Nedstigningen i det indre fører endvidere fra håbet om at finde en fast substans, finde sit "selv«, til erkendelsen af det håbløse heri. I begyndelsen, da Marlow stadig har håbet i behold, hedder det: »Jeg kan ikke lide arbejde...men jeg kan lide det der ligger $i$ arbejdet - muligheden for at finde mig selv« (s. 41). Som vi har set modificeres dette senere, arbejdet og i videre forstand det borgerlige liv anskues som på én gang udelukkende det virkelige jeg og værnende imod mørket inderst inde. Dér finder Marlow netop »noget, der var helt uden substans« (s. 66), hvilket ikke blot går på forhold i Marlow, men på hele det usubstantielle territorium Kurtz hersker over.

Opdagelsen af det flydende, udefinerlige indre er en dybere erkendelse end fastholdelsen af det afgrænsede jeg, men ikke desto mindre et forhold med lige så lidt »realitet«. Dette er den »fuldstændige visdom«, som Kurtz er nået frem til og som Marlow tager ved lære af. I forbindelse hermed rejses spørgsmålet om, hvorvidt det er muligt at kende »den anden« eller »de andre«; hvor ens viden om en selv blot kan være det uafgrænsede i den platoniske betydning: jo mere man ved desto mindre, så kan man i forhold til medmennesket »kun se det bareste skin, og kan aldrig vide, hvad det virkelig betyder« (s. 41). Udsagnet om det umulige $i$ at erkende eller nå ind til medmennesket, forlænges til et udsagn om menneskets fundamentale ensomhed: »Det er umuligt at gengive livsfornemmelsen i nogen givet periode $i$ ens tilværelse - det der udgør dens sandhed, dens mening - dens så fine og gennemtrængende inderste væsen...Vi lever som vi drømmer - alene« (s. 39). Denne ensomhed er det 
også, som Kurtz finder derude i de egentlige egne af tilværelsen og som ligger bag hans »rædslen, rædslen«. Men spørgsmålet om, hvad det er muligt at se i sig selv og andre, går samtidig i retning af, hvad der har betydning, hvilke forhold der er væsentlige og erkendelige. Marlow forsikrer Kurtz' forlovede om, at "jeg kendte ham så godt, som det er muligt for et menneske at kende et andet « (s. 106). Mens Kurtz skrumper ind $\mathrm{i}$ det ydre, tiltager hans stemme $\mathrm{i}$ styrke, den får en lyd som »råb igennem en megafon « (s. 93). Til sidst kendes Kurtz kun ved denne enorme stemme, der danner en grel kontrast til hans fysiske fremtoning: »En stemme! Den var alvorlig, dyb, vibrerende, mens manden selv så ud som han ikke magtede at hviske« (s. 86). Kurtz bliver et fænomen, der høres og ikke ses; det samme gælder da Marlow efter et møde med en russer spørger sig selv om han overhovedet »nogensinde virkelig havde set ham « (s. 90), og Marlow selv bliver for sine tilhørere en »stemme« efterhånden som mørket lægger sig. Den æteriske stemme gentager udsagnet om begrænsningerne $\mathrm{i}$ kendskabet til »den anden«, men samtidig ligger heri en afskrivning af det ydre, fysiske i videste forstand. Det understreges af, at Marlow til slut overhovedet ikke tillægger diskussionen om, hvad Kurtz var - forretningsagent, journalist, musiker osv - nogen betydning, men blot fastholder »stemmen« og dens udsagn, nemlig rædslen, som det eneste væsentlige. Mørket lægger sig i Heart of Darkness over de ydre, objektive forhold, som bliver »betydningsløse eller anses for uerkendelige for individet, der $\mathrm{i}$ stedet henvises til sit indre subjektive univers.

Kurtz er også »midlet imod det historiske « $\mathbf{i}$ form af den primitive vitalitet, som er $\mathbf{i}$ naturen. Den frigøres og flyder ham $\mathrm{i}$ årene idet han uddriver »videnskab« og »fremskridt«, det tunge historiske arvegods han havde $\mathrm{i}$ sig til fingerspidserne; herimod er hans selvdestruktion rettet og derfor intet under, at den har så kolossalt et omfang. Kurtz brænder som i helvede, men af asken opstår et nyt skabelsesgrundlag. Selvdestruktionen bringer ham helt ned på et primitivt, infantilt stadie, Kurtz bliver et barn: "han var ikke meget tungere end et barn « (s. 95) og »han var foragteligt barnagtig« (s. 97). Men barndommen er som urtilstanden også tidløshed, naturlighed, umiddelbarhed og spontan, vital udfoldelse. Disse værdier har vi set danne et modbillede til forholdene $\mathrm{i}$ civilisationen, hvor de havde utopisk karakter. Men når det gælder den kunstneriske skabelse har de gyldighed. Som legemliggørelsen af dem kan Kurtz fremkomme med sin radikale erkendelse, og de udgør det uhistoriske reservoir, Marlow øser af som fortæller. Når vi dykker ned under den historiske overflade får vi en kunst, der er holdt i naturens former og som har bevaget sig fra de 
overfladiske emner, dem i tiden, til de væsentlige, de evige.

I overensstemmelse med tilstedeværelsen af på én gang en ordinær realisme med et historisk indhold og en modernistisk problematik - den $i$ grunden stillestående verden, det umulige $\mathrm{i}$ en objektiv fremstilling af den, opgøret i det hele taget med objektive størrelser og den beskæftigelse med det subjektive, som følger heraf m.m. - brydes i Heart of Darkness konventionelle og moderne fremstillingsformer. Med Marlow som fortæller af en faktisk spændende historie med et lineært forløb har vi en traditionel fortælleform, som imidlertid udhules på flere måder. Handlingen, hvori de historiske forhold søges fremstillet, sprænges indefra idet de erkendelser og udsagn, som fremkommer undervejs, blot bidrager til at understrege handlingens resultatløshed. Sagt på en anden måde: undsigelsen af udviklingstanken på idéplanet er samtidig en undsigelse af romanens lineære forløb. Eksempelvis er det stillestående i romanens univers direkte iagttageligt i det forhold, at den hændelse Marlow beretter om opløser sig i mangfoldige »statements« af filosofisk karakter, hvori netop det ydre - action, miljø- og personbeskrivelse osv, som ér tilstede - betragtes som betydningsløst. Handlingen er mindre betydningsdannende end den er udløser af filosofiske udsagn, endda om livets betydningsløshed. Man kan sige, at de facts Marlow bygger sin fortælling på problematiseres for $\mathrm{i}$ sidste ende at tilsidesættes i diskussionen om objektive værdier. Marlow gennemskuer den traditionelle tilværelsesopfattelse, som han dog fastholder som en nødvendig illusion, og udvikler en moderne. Svingningerne imellem den nødvendige, men overfladiske fortolkning og den moderne opdagelse af »altings flygtighed « (s. 100) slår igennem i formen. Hvor Marlow her karakteriserer en samtale med Kurtz, beskriver han samtidig rammende dobbeltheden i fremstillingen: "Jeg dér foran ham vidste ikke, om jeg stod på den faste grund eller svævede $\mathrm{i}$ luften. Jeg har hele tiden fortalt jer hvad vi sagde... men hvad nytter dét. Det var almindelige ord fra hverdagen - de velkendte, vage lyde, man udveksler hver eneste vågen dag i livet. Men hvad så? Der var bag dem, som jeg føler det, den skrækindjagende suggestivitet over ord der høres i drømme, ord der udtales i mareridt« (s. 94).

Lagene $i$ teksten forholder sig som dag og nat, lys og mørke, som det velkendte (traditionelle) præget af bevidst og fornuftsmæssig styring, der har en uudgrundelig dybde af irrationelt og ubevidst stof under sig, hvilket udgør det inderste og dermed autentiske lag, som er identisk med Marlows uhistoriske reservoir. Fortælleren Marlow giver undertiden los som den hæmningsberøvede på briksen, her bringer han ubevidst Kurtz' forlovede på bane, hvilket ovenikøbet sker i en passage, hvor han giver en 
karakteristik af oplevelsen i junglen, der samtidig er et ekstremt billede på denne vilkårlige, umiddelbare fortælleform: »»Alle var ikke meget mere end stemmer,- og mindet om selve den tid bliver tilbage rundt om mig, uhåndgribeligt, som en døende vibration fra én umådelig plapren, tåbelig, grusom, ussel, barbarisk, eller simpelthen tarvelig, uden nogen art af mening i. Stemmer, stemmer - endda pigen selv - nu -«. Han tav stille i lang tid. »Jeg manede hans gavers ånd ned tilsidst med en løgn «, begyndte han pludselig. »Pige! Hvad? Nævnede jeg en pige? «« (s. 68). Romanens indre fortælleform behøver vi imidlertid ikke slutte os til, den påpeges direkte af Marlow og af den kommenterende fortæller. Hvor Marlow et øjeblik holder inde, gør fortælleren opmærksom på besværligheden med at fastholde historiens substans, materialitet: »Jeg lyttede på vagt efter den sætning, efter det ord, der ville give mig nøglen til dette svage ubehag, hans beretning indgav én, imens den ligesom formede sig selv, uden et menneskes læber $\mathrm{i}$ den tunge natteluft over floden « (s. 39). Marlow selv erkender, at hans fortælling trækker på »den drømmefølelse, som gennemsivede alle mine dage i den tid« (s. 59) og således tilkendegiver han sine tvivl om sin fortællings soliditet og følelsen af, at det egentlig er den umulige genfortælling af en drøm han er i færd med: »Kan I se historien? Kan I se noget som helst? Det er for mig, som om jeg sidder og prøver på at fortælle en drøm - gør et forgæves forsøg, fordi ingen beretning om en drøm kan gengive drømmefornemmelsen, denne sammenblanding af urimelighed, overraskelse og forvirring $i$ en rystelse af kæmpende oprør; denne forestilling om at være holdt fanget af det utrolige, der er det inderste væsen i drømme« (s. 38-39). Således gør romanen opmærksom på sin egen delvise immaterialitet og det er da også tilstedeværelsen $\mathrm{i}$ et sådant vildnis man ofte føler som læser - den læser Marlow også henvender sig til i ovenstående. Selv om der ér orienteringspunkter i ydre data, opstår samtidig en uvirkelig verden idet Marlow overgiver sig til sine subjektive indtryk, hvori det ydre fragmenteres og gengives netop på den absurde måde, som kendetegner drømmearbejdet, hvilket jo også er en undsigelse af historiens logiske forløb, og denne opløsning af den ydre verden i subjektive indtryk må ses i sammenhæng med den omtalte introvering, med den omstændighed at den ydre problematik bliver symbol på den indre.

Som Marlow finder en nødvendighed i den »hvile« fra de ulidelige sandheder, som civilisationen giver, således er det ham en lise at vende tilbage til en mere konkret fortælleform, hvilket naturligvis er ensbetydende med, at han slipper den direkte og smertefulde frembringelse fra dybet - af sandhederne. Da han er længst nede og dermed mest 
umiddelbart fortællende - »»Absurd!« råbte han. »Dette ér det værste at prøve på at fortælle«« (s. 67) - kan han samtidig ønske: »Absurditet - eksplodér!« (s. 68). Ikke tilfældigt er Marlows beretning mest behersket $\mathrm{i}$ begyndelsen og slutningen, men behersket er den hele vejen igennem for så vidt det er den kølige jeg-fortæller, der formidler den.

Det er også nødvendigheden i kunstnerisk fremstilling af fornuft og styring $\mathrm{i}$ betydningen form og struktur, der meddeles. Blandt andet som en følge af opdagelsen af det formløse bevidsthedsmateriale og af det udefinerlige formløse virkelighedsmateriale $\mathrm{i}$ det hele taget, skærpes i moderne romaner formopmærksomden og Heart of Darkness er ingen undtagelse i så henseende. Således er den bog om sømandsskab Marlow finder mere end en kontrast til Heart of Darkness. Bogen - »En undersøgelse af nogle Hovedpunkter i Sømandsskab« af en Tower, måske Towson eller Towser, Marlow kan ikke præcist bestemme navnet da bogens ophold $i$ junglen har gjort det utydeligt - er en meget stringent fremstilling af skibes mekanik, fremdriftsmidler. Efter længere tids ophold i junglen er bekendtskabet med dette saglige og velordnede univers en lise for Marlow, han behandler den med »den størst mulige ømhed« (s. 54) og da han må lægge den til side, hedder det: "Jeg forsikrer jer, at holde op med at læse i den, var ligesom at rive sig ud af den tryghed, der er ved et gammelt og solidt venskab« (s. 54). Bogen står naturligvis som eksempel på en fremstillingsform Heart of Darkness vil væk fra, derfor kaldes den også »denne forbløffende antikvitet«(s. 54), men når Marlow samtidig kan fastslå, at den er »umiskendelig virkelig « (s. 54), så skyldes det dens gyldighed som ekstremt billede på det saglige og udvendige i den realisme, der spiller en rolle i Heart of Darkness, den rummer også et selvironisk aspekt, men virkelig er ikke mindst dens funktion som symbol på den velordning af materialet, på den form og struktur, som ikke bliver mindre påkrævet $\mathrm{i}$ nybruddet. Forfatternavnet Tower kan pege på nødvendigheden af et solidt fundament, noget borgfast til at omslutte og fastholde, og Marlows besvær med at bestemme navnet har måske adresse til de problemer med formen, som nyorientering giver, hvor bogens emne, teknik (styring), spæder til. I øvrigt bringer »Tower« et klassisk vartegn for London, byens ældgamle fæstning, i hu, hvilket giver trygge forbindelser bagud, men samtidig nedkalder navnets utydelighed ironi over historien og dens monumenter.

Om Tower oplyses det, at han var »Skibsfører i Hans Majestæts Marine « (s. 54), hvormed der tilføjes en kontrast imellem denne sømandsforfatter på sikker grund og Marlow, der navigerer i ukendt og uvejsomt terræn - som sømand og fortæller. Kontrasten imellem 
navigation (i denne dobbelte betydning) før og nu og imellem forskellige navigationsformer på samme tid, er allerede angivet i starten, hvor jeg-fortælleren sammenligner Marlows sømandshistorie med traditionen inden for dette fag: »Sømænds historier har en direkte enkelhed, hvis hele betydning ligger inde i skallen, $i$ en knækket nød. Men Marlow var ikke typisk...og for ham lå en episodes betydning ikke inden i som en kærne, men udenfor, og omspændte den historie, som bragte den frem, men kun sådan som en glød bringer en varmedis frem, så den antager lighed med disse tågede glorier, der nogen gange synliggøres af måneskærs spøgelsesagtige lysen« (s. 8). Traditionen for simpelhed og logik og en indre substans, en mening, er passé hos Marlow, hvis fortælling som bekendt blander lys og mørke og skaber et univers, der er sløret som en tågedis eller som den »tågede glorie«, der i slutningen genfindes omkring hovedet på Kurtz' forlovede. Der er en verden og en tilværelsesforståelse til forskel. Det gør jeg-fortælleren klart i denne passage, der er en præcis prolog til Heart of Darkness som helhed. Marlow er »en vandringsmand« (s. 8), har det ustadige i blodet og den opgave at fortolke Kurtz' »smil med udefinerlig mening« (s. 96), hvorfor fortælleren fra begyndelsen frarøver os håbet om at finde en fast kerne $\mathrm{i}$ historien: »Vi vidste at $\mathrm{nu}$, før ebben begyndte at løbe, var vi forudbestemt til at høre om en af Marlows resultatløse oplevelser« (s. 11).

Interessen for at besejle floden får Marlow da han i et butiksvindue ser den på et landkort, hvor den tager sig ud som en mægtig slange: »slangen havde forhekset mig« (s. 12). Rejsen beruser fordi den skal slukke en enorm kundskabstørst. Som vi har set er der ikke bund i flasken: mørket han bevæger sig ind $\mathrm{i}$ er »uigennemtrængeligt« og det vil også sige uudgrundeligt. Som slangen der har »sin hale borte $\mathrm{i}$ landets dybder « (s. 12), er der ingen ende på erkendelsesmulighederne. Opdagelsen af det bundløse udløser ganske vist angst, men samtidig en jubel over en nyvunden frihed. Således kan Marlow udtale sig nærmest triumferende om bevidsthedens ubegrænsede kapacitet: »Menneskets bevidsthed er i stand til enhver ting - fordi alle ting er $\mathrm{i}$ den, hele fortiden så vel som hele fremtiden« (s. 52). Der åbnes for en uanet skaberkraft med denne bevidsthed, som også er kunstnerens over for sit objekt, det uudtømmelige kunstneriske materiale $\mathrm{i}$ som uden for mennesket. Bortfaldet af det objektive værdigrundlag betyder en ny kunstnerisk frihed, kunstneren bliver herre i eget hus, som er virkelighedens uransagelige veje, den ydre såvel som den indre jungle. Men uudtømmeligheden klinger ikke helt rent ved siden af udsagnet om, at »alt er til enhver tid det samme«, det dybest set uforanderlige ved siden af omskifteligheden. Medieringen herimellem 
kan udtrykkes som: „den uendelige kombination af de samme (evige) elementer «, hvilket igen bringer friheden i stue med klaustrofobien. Den moderne kunstner er stillet over for det paradoks, at de uanede og ubegrænsede muligheder rummer gentagelsens veje - samme vilkår der galder for vandringsmanden i labyrinten. Med autoriteternes bortfald bliver forfatteren som »Gud i sit univers«, skabelsens herre, men han har ikke samme mulighed for at give lys i mørket. Kunst og erkendelse som det der fortrænger mørket, er der ikke ubetinget tale om i Heart of Darkness. Meget kommer for dagen, især usandhederne på overfladen, men samtidig er der en dybere sandhed, som hører mørket til, den evige, uudsigelige, Kurtz tager med sig i graven.

III.

Beruselsen af det uudtømmelige og uudgrundelige ved tilværelsen bliver et træk, som fra og med Flaubert $\mathrm{i}$ stigende grad ses hånd $\mathrm{i}$ hånd med påpegningen af tilværelsens klaustrofobiske snæverhed. Dobbeltheden af ubegrænset frihed og indesluttethed tager livet af Kurtz, men på ét plan i Heart of Darkness har indesluttetheden (endnu) ydre, timelige årsager. Fremover omsluttes den yderligere af evigheden. I Ulysses er dobbeltheden slået helt igennem. Det er en væsentlig grund til, at det dramatiske vi endnu finder i Heart of Darkness, er ude i Ulysses og hos andre af den tids moderne forfattere. Rædselsskriget er forstummet hos Bloom, som bevæger sig stilfærdigt $\mathrm{i}$ storbylivets og altså livets på en gang stadigt skiftende strøm og lukkede kredsløb - »gennem evigt skiftende baner i det aldrig skiftende rum « (Ulysses s. 660). ${ }^{8}$

Handling og kronologi bryder sammen i Heart of Darkness og inderst inde opstår det uendelige og cykliske, som opfattelses- og gengivelsesmæssigt kommer til at beherske de moderne romaner. Det cirkulære er mest udtalt i den skildring af det indre menneske, som Heart of Darkness forbereder med det dyk ned i bevidstheden, der st $\emptyset$ der på det udefinerlige og afgrundsdybe ved karakteren. I den flydende og centrumløse streamof-consciousness er handlingen mindst og den udtrykker et verdenssyn, som pointerer det relative og subjektive ved tilværelsen. Den er Virginia Woolfs teori omsat fuldtud i praksis - $\gg$ Min teori er, at tiden og den aktuelle begivenhed praktisk talt ikke eksisterer « (s. 105) ${ }^{9}$ - og den understreger det på én gang åbne og lukkede univers: ingen grænser i det indre, $i$ den enkelte bevidsthed, men denne er afgrænset ved en evig mur fra de andre bevidstheder. Det indre unddrager sig den kronologiske tid 
og den moderne roman som helhed forkaster det lineære forløb i og uden for værket. Den udtrykker den relativistiske tidsalder, men med nivelleringen af de historiske perioder igennem det uendelige og cykliske forsvinder på en måde den moderne tidsalder ud af den moderne roman - "Navne skifter: det er det hele « (Ulysses s. 348). ${ }^{10}$

Den senere moderne roman erstatter Conrads mareridtsagtige fremstilling af ensomheden med en anderledes stilfærdighed, som blot i højere grad understreger det tilstandsmæssige. Det stilfærdige og hverdagsagtige »sidder over « $i$ den tidlige modernisme, idet allerede Flaubert fastlagde det. Den banale, konkrete hverdag fylder de moderne romaner ud, men i de bevidstheder, som den afspejles igennem, fremkommer udsagn, som potenserer det verdenssyn vi fandt i Heart of Darkness. I Ulysses er tomheden og uvisheden tilstede på alle planer, mennesket er overladt til "et mikro- og makrokosmos, der uundgåeligt er bygget på tomhedens uvished « (Ulysses s. 625). Uvisheden er mindst i det jordnære, konkrete, men selv her er den naturgiven, som hos Molly, der har bedraget som en del af sin natur - den ypperlige, feminine natur, der udtrykker det inderste i Ulysses, også som den form Molly udtrykker sig i, en stream-ofconsciousness helt uden interpunktion, vital og umiddelbar og unddragende sig tid og fakta, Joyces bud på den kunst holdt i naturens former, som åbenbarede sig under overfladen i Heart of Darkness. Mens Odysseus triumf ved hjemkomsten til Ithaca er absolut - hans resolutte genindsætten sig som herre i huset - er Blooms relativ: Molly bedrager ham under hans fravær og hvor vidt han når denne morgen i sengen med Molly forbliver uvist; da Molly repræsenterer det menneskelige, jordiske, og dermed den mulige vished, stabilitet, vil Blooms besiddelse af hende altid være ufuldstændig. Ingen kan gøre et absolut krav på Molly.

Naturloven i Ulysses er også den nådesløse Bloom her omtaler: »enhver æder enhver anden. Sådan er livet i sidste instans« (Ulysses s. 123). Vi genfinder jungleloven fra Heart of Darkness og samtidig anskuelsen af det civiliserede liv som en overfladisk beskyttelse imod de mørke, men naturlige magter, hvilket Bloom ser gennemført helt ned i begravelsesritualet: »At beskytte ham så længe som muligt, selv i jorden. Irlænderens hus er hans kiste (Ulysses s. 112). Inderst inde hos Conrad og Joyce er uvisheden og den grufulde natur, men hos Joyce har naturen genvundet den anden side, som forsvandt hos Conrad med ophævelsen af modbilledet. Tilværelsen ér meningsløs, men samtidig "god nok« i sin konkrete menneskelighed, som Joyce især illustrerer med det erotisk-libidinøse, en konkret glæde og kunstnerisk inspiration, men tillige en urkraft i mennesket. Erotikken er kilden til det bedrag, som afspejler den 
fundamentale uvished, men samtidig et livsbekræftende princip; den banale hverdag rummer også den rigdom og frodighed, som Molly kendetegnes ved. Vi får således en ja-nihilisme, hvormed Joyce fjerner den rædsel, der fyldte Conrads univers.

Friheden kom dog tilsyne i Heart of Darkness som den skaberkraft vi så spy ud, da traditionens åg løftede sig. Meningsløsheden bliver friheden til at skabe og Heart of Darkness viser overgangen fra realismens virkelighedsgengivelse til den moderne romans betoning af kunst som skaber af virkelighed. Kunstneren i den relativistiske verden ser sig stillet over for et »materiale«, som på en gang altid er det samme og fuld af uendelige muligheder. Den moderne roman fastholder det evige vilkår og herunder den konkrete virkelighed, som er menneskets lod til alle tider, men vil samtidig igennem en helt ny litterær form åbne for en ny erkendelse af verden: »Jeg vil i min sjæls smedje skabe mit folks uskabte samvittighed « (s. 228), ${ }^{11}$ som forfatterspiren Stephen siger i $A$ Portrait of the Artist as a Young Man, der er det litterære manifest, hvori Joyce pejler sig ind på sine modernistiske standpunkter. Joyce så $\mathrm{i}$ kunsten erkendelsesmediet par excellence, men for en erkendelse, som aldrig sluttes: „En ny konstant bevægelig, ufattelig og uforgængelig væren « ( $A$ Portrait s. 154) skulle fylde universet, som i særdeleshed i Finnegans Wake, der ville være åben for en uendelig fortolkning. Men det skete i en form, som sprængte romanformen. Finnegans Wake er kulminationen på den proces, der sættes i gang i Heart of Darkness; her var den klassiske realisme under nedbrud og senere forlades den helt, men ikke nok med det: med de tiltagende æstetiske eksperimenter nås efterhånden en form, som med sit stærke poetiske islæt tenderer til at opløse romanformen. Heart of Darkness sliber kniven til det litterære fadermord, som den moderne roman begår, men denne ender med at bringe sit eget eksistensgrundlag i fare.

Joyce havde ingen skrupler derved, men andre forfattere, som Virginia Woolf, modvirkede opløsningen af romanformen, hvilket dog også hang sammen med et skift i tilværelsesopfattelse. I The Waves ${ }^{12}$ geninddrager Woolf traditionelle virkemidler, som medvirker til at understrege en grundlæggende sammenhæng i tilværelsen, hvormed hun fjerner sig fra den rene moderne form i Mrs Dalloway og To the Lighthouse, hvis primære udsagn gik på ensomhed og meningsløshed. I The Waves er en markant natursymbolik anbragt på et indre poetisk plan og modspillet imellem indre og ydre minder meget om det i Heart of Darkness. Men i Heart of Darkness blev naturen en destruktiv kraft, mens den i The Waves symboliserer en evig harmoni og sammenhæng, hvor her differentiering 
og meningsløshed bliver et ydre, tidsbestemt fænomen. Joyce gjorde i Ulysses en gang for alle op med konventionelle virkemidler og den poetiske kraftanstrengelse i Finnegans Wake er en radikal understregning af tilværelsens »kaotiske substans «, ${ }^{13}$ mens det i The Waves er, at »fuldstændigheden triumferede over kaos...kaos' herredømme er ovre« (The Waves s. 43 og 104). Den moderne skrivemåde vi så spire frem i Heart of Darkness, ophører som toneangivende i 30'erne. Finnegans Wake er atypisk, mens The Waves indvarsler en renæssance for den traditionelle skrivemåde.

Selv om den moderne roman potenserer det verdenssyn vi fandt i Heart of Darkness, bliver samtidig en central bestræbelse indramningen af noget universelt midt i flygtigheden. Der kommer en substans ind, som ikke ses i det mere bundløse, i højere grad angstfremkaldende univers i Heart of Darkness. De »suveræne livsytringer« Joyce især lader Molly udtrykke, er en del af denne substans, hvis grundelement $\mathrm{i} \emptyset \mathrm{vrigt}$ er den universelle hverdag, vi følger Bloom igennem. I Ulysses er intentionen at sammenfatte menneskets universelle lod, det altomfattende, at give »et miniaturebillede af den verden vi lever i« (Ulysses s. 579). Og Bloom er almenmennesket: »Kristus eller Bloom er hans navn eller, når alt kommer til alt, et hvilket som helst andet« (Ulysses s. 575). Det samme gælder i Finnegans Wake, der vil skildre en universalbevidsthed. Trods relativismen giver det $\mathrm{i}$ Ulysses en virkelighedsdybde, som udtømtes i den tidlige modernisme og forsvandt $i$ de modernistiske retninger, der fulgte efter den moderne roman.

Heart of Darkness havde på to planer repræsenteret to forskellige opfattelses- og gengivelsesformer: realismen, der bygger på en enhedsopfattelse af tilværelsen og modernismen, som betoner det relative, mangfoldige og subjektive. Kendetegnende for tiden efter sammenbruddet af den »store realisme « er, at der ikke igen opstår én herskende kunstform, men utallige og vidt forskellige. Fastholdes »verdenssynet « kan man dog skelne imellem to retninger $\mathrm{i}$ den nyere tids kunst, som præger debatten og på skift tiltvinger sig en dominerende rolle. Groft sagt ligger der bag de brede, udadvendte, episke fortællinger faste verdensbilleder, spændende fra kristne til socialistiske, men fællestrækket er alligevel netop helhedsopfattelsen, mens de modernistiske retninger falder sammen ved at understrege det relative og atomiserede ved tilværelsen. Modernismen fortsættes f. eks.i »le nouveau roman« og hos Beckett, som fører det meningsløse og ensomheden ad absurdum, men vi finder ikke længere de suveræne livsytringer og normaliteten, men i stedet det forvrængede og mareridtsagtige. 
Springer vi frem til vore dages postmodernisme ser vi det modernistiske nedbrud gentaget - af det Lyotard kalder den »store fortælling «, hvormed han bl.a. mener de ideologier og æstetiske udtryksformer, som bygger på enheds- og helhedsopfattelser - og genkomsten af "mangfoldigheden, paradokserne og forskellene. Det postmoderne erkendelsesrum har intet centrum, men består af et labyrintisk netværk af provinser og sprogspil. Det er åbent, uden grænser og fyldt af uregerlige bevægelser. Men i dette rum bliver også forestillingen om det menings- og historieskabende subjekt eller individ reduceret til en illusion« (s. 47). ${ }^{14}$ Det er det erkendelsesrum - og formen er også ramt - vi har set udspringe hos Conrad og som senere udfoldede sig i den moderne roman. Men der er væsentlige forskelle. I postmodernismen er, igen med Else Marie Bukdahls ord, "det globale eller universelle blevet reduceret til indholdstomme størrelser «(s. 91). ${ }^{15}$ Der er ikke længere tale om midt i værdiopløsningen at ville finde ny grund, som den Joyce fandt i det basale, hverdagsagtige, hvilket trods alt gav et indhold af en betydelig substans. I stedet for en relativitet ikke blot skildret igennem, men også opvejet af en konkret virkelighed, får vi i postmodernismen kombinationen af »det grænseløse og det tomme « (s. 59, min understregning), ${ }^{16}$ hvormed der på en måde gribes tilbage til det bundløse, vi fandt hos Conrad. Men både hos Conrad og i den senere moderne roman var der en klar skelnen imellem en ydre virkelighed og en indre og mere oprigtig, et fors $\emptyset \mathrm{g}$ på at uddestillere områder, der var mere virkelige end andre, mens postmodernismen understreger gyldigheden af »alle former for virkelighed « (s. 47). ${ }^{17}$ Det samme gør en moderne dansk lyriker, Pia Tafdrup, der ser tidens digte fremkaldt af $\gg$ den rene relativisme« (s. 11), ${ }^{18}$ som hun beskriver således: "Verden er ikke en enhed. Enhver forestilling om sammenhæng er væk, enhver tro på orden er afløst af det mangfoldiges princip...alt flyder...alt transformeres, omformes, omdannes i en uendelig proces. I et rum uden grænser...Intet er mere gyldigt end noget andet. Det ene øjeblik ikke mere sandt end det andet. Alt er virkelighed« (s. 10-11). 19

Man ser i dette helt åbne, grænseløst uendelige univers, en udvidelse, men det er imidlertid så rummeligt, at ikke blot tomheden, men også lige-gyldigheden får mere plads. Udsagnet om det åbne og uendelige fremkommer som en reaktion imod det tyranniske, man ser $\mathrm{i}$ enheds- og helhedsopfattelser, men forbliver et endeligt udsagn om, at sådan ér verden. Derved åbner man ironisk nok for det enhedstyranni, man opponerer imod - for »når alt er virkelighed " og "intet er mere gyldigt end noget andet«, godtages tyranniet indirekte. Men man bliver også selv 
tyrannisk. Med det postmoderne erkendelsesrums vidt åbne karakter opstår en uangribelighed - man kan altid henvise til mangfoldigheden, paradokset - som tankevækkende nok også kendetegner de tyranniske helheder. Det verdenssyn, der hævder, at »alt flyder«, er i sidste instans ikke mindre påtrængende. Jo mere grænseløs uendeligheden bliver, desto mere synes indesluttetheden at trænge sig på - det grænseløse og dét tomme, som rummer indholdsløsheden. Der er også en tanke $i$, at Søren Kierkegaard forbandt »Tomhed og Indholdsløshed« (s. 215) ${ }^{20}$ med indesluttethed: »Indholdsløshedens Form er netop Indesluttetheden « (s. 216), ${ }^{21}$ hvilken var en væsentlig kategori $\mathrm{i}$ hans bestemmelse af det dæmoniske, et ældre udtryk for et moderne fænomen: »Det hjælper kun lidet at giøre det Dæmoniske til en Uhu, som man perhorrescerer og dernæst ignorerer, da det er mange Aarhundreder siden, at det fandtes i Verden. Denne Antagelse er en stor Taabelighed; thi det har maaskee ikke nogensinde været saa udbredt som i vore Tider, kun at det nuomstunder især viser sig $\mathrm{i}$ de aandelige Sphærer $\left(\right.$ (s. 218). ${ }^{22}$

\section{Noter}

1. Anvendt udgave er Penguin Books 1979. Citaterne er oversat ved hjælp af Jørgen Sonnes oversættelse, Mørkets hjerte, Fremad 1986, hertil henviser sidetallene i parentes. Dog har jeg flere steder modificeret Sonnes oversættelse. Nærværende analyse af Heart of Darkness er en omarbejdning af et afsnit i mit speciale Den modeme roman, AIL 1986.

2. Granite and Rainbow, The Hogarth Press, London 1958/1981. Min oversættelse, FLH.

3. Som Flaubert siger i sin Correspondence, citeret efter Arnold Hauser, Kunstens og litteraturens socialhistorie, bd. 2 s. 302, Rhodos.

4. Der tales om Kurtz' mulige venden tilbage fra »et eller andet gyseligt Intetsteds« (s. 97), og han kaldes for »dette indviede genfærd, der kom længst ude fra Intetsteds«(s. 70).

5. Begrebet hentet fra Fredric Jameson, som i en analyse af Lord Jim taler omde sinddæmningsstrategier«, hvormed Joseph Conrad i Lord Jim skaber »et indbygget substituerbart fortolkningssystem, hvorved læseren kan fortolke teksten på mindre offensive måder« (s. 266, min oversæettelse, FLH). Analysen findes i bogen The Political Unconscious. Narrative as a Socially Symbolic Act, Methuen \& Co. Ltd, London 1981/1983.

6. Senere kaldes Kurtz ligefrem for »et levendegjort billede af Døden, udskåret i gammel elfenben«(s. 85).

7. Friedrich Nietzsche: Historiens Nytte, Gyldendals Uglebøger 1962. Fra Unzeitgemässe Betrachtungen, som udkom i 1874. 
8. Penguin Books, 1922/1984. Ti1 oversættelse af citaterne er Mogens Boisens oversættelse anvendt, Martins Forlag 1969, hertil henviser sidetallene i parentes.

9. A Writers Diary, Triad Panther, 1953/1978. Min oversættelse, FLH.

10. I Ulysses genfinder vi den historiske ironi udtrykt ved henvisningen til romerne, f. eks.: "Vi har også romersk lov« (s. 131).

11. A Portrait of the Artist as a Young Man, Granada 1916/1983. Min oversæettelse, FLH.

12. Penguin Books, 1931/1976. Min oversættelse, FLH. Med The Waves bevæger Woolf sig på flere måder væk fra det, der var karakteristisk for den moderne roman: »handlingen« vinder indpas og med »enetalen « forlades det intrasubjektive område, eksempler på de mere traditionelle virkemidler, som ganske vist er med til at opbygge et overfladeplan, der negeres, men som samtidig tjener til at understrege "sandheder« på det indre plan; således anvendes enetalen udpræget til at skabe dialog, sammenhæng imellem personerne, hvor sammenhængen, det fælles, står i modsætning til det udsagn om den fundamentale ensomhed, som var nedlagt i de adskilte indre monologer i Mrs Dalloway (1925) og To the Lighthouse (1927).

13. Umberto Eco om Finnegans Wake i Das offene Kunstwerk, Suhrkamp Tashenbuch, 1962/197S. Min oversættelse. FLH

14. Else Marie Bukdahl: "Den postmoderne billedkunst og dens forudsætninger«, i Kritik 72, 1985.

15. Else Marie Bukdahl: „Blændværker i kunsten og samfundet«, i Spejl og Labyrint, katalog til efterårsudstillingen på Sophienholm 1984.

16. Else Marie Bukdahl: „Den postmoderne billedkunst og dens forudsætninger«.

17. Ibid.

18. Pia Tafdrup: Forord til antologien Transformationer. Poesi 1980-1985, Systime 1985.

19. Ibid.

20. Søren Kierkegaard: »Begrebet Angest«, Samlede Varker, bind 6.

21. Ibid.

22. Ibid. 